Nie, Z.N.; Zollinger, R.P.; Behrendt, R. 2015. Impact of deferred grazing and fertilizer on herbage production, soil seed reserve and nutritive value of native pasture in steep hill country of southern Australia. Grass and Forage Science 70: 394-405.

Sheath, G.W.; Bircham, J.S. 1983. Grazing management in hill country: pasture production. pp. 41-45. In Proceedings of the Ruakura Farmers' Conference. Hamilton.

Sheath, G.W.; Hay, R.J.M.; Giles, K.H. 1987. Managing pastures for grazing animals. pp. 6574. In: Livestock feeding on pasture. Ed. Nicol, A.M. New Zealand Society of Animal Production, Hamilton.

Sheath, G.W.; Webby, R.W.; Pengelly, W.J. 1984 Management of late spring-early summer pasture surpluses in hill country. Proceedings of the New Zealand Grasslands Association 45: 199-206.

Smith, M.E.; Dawson, A.D. 1977. Hill country grazing management. Proceedings of the New Zealand Grassland Association 38: 47-55.

Tozer, K.N.; Marshall,A.J.; Sedcole, J.R.; Edwards, G.R. 2007. Ripgut brome (Bromus diandrus) distribution in relation to topography and management on seven high country properties in the South Island. New Zealand Plant Protection 60: 168-173.

Waghorn, G.C.; Burke, J.L.; Kolver, E.S. 2007. Principals of feeding value. Managing pastures for grazing animals. pp. 35-59. In: Pastures and supplements for grazing animals. Ed. Rattray, P.V.; Brookes, I.M.; Nicol, A. M. New Zealand Society of Animal Production, Hamilton.

\title{
Estimation of ergovaline intake of cows from grazed perennial ryegrass containing NEA2 or standard endophyte
}

C.C. EADY ${ }^{1}$, J.R. CORKRAN ${ }^{1}$, K.M. BAILEY ${ }^{1}$, G.A. KERR ${ }^{1}$ and A.M. NICOL ${ }^{2}$ ${ }^{1}$ Agriseeds Ltd, 2547 Old West Coast Road RD1, Christchurch, 7671, New Zealand ${ }^{2} A M N$ Consulting, 1248 Old West Coast Road, RD 1, Christchurch 7671, New Zealand

$$
\text { ceady@agriseeds.co.nz }
$$

\section{Abstract}

Ergovaline concentration was measured monthly from December 2015 to April 2016 in herbage of perennial ryegrass pastures containing NEA2 or standard endophyte (SE) in the Waikato, Manawatu and Canterbury. Ergovaline concentrations were then combined with estimated pasture intake, pasture botanical composition and cow liveweight data from experimental dairy farm systems in the Waikato and Canterbury to estimate dairy cow ergovaline intake (mg/kg LW ${ }^{0.75} /$ day). For the diploid ryegrass 'Trojan' with NEA2 estimated ergovaline intake ranged from 0.01 to $0.029 \mathrm{mg} / \mathrm{kg} \mathrm{LW} \mathrm{LW}^{0.75} / \mathrm{day}$, levels at which no significant animal production effects have been reported. Ergovaline intake of tetraploid ryegrass 'Bealey NEA2' was at least an order of magnitude lower than this. For the diploid ryegrass, 'Bronsyn' with SE, ergovaline intake was 0.016 to $0.056 \mathrm{mg} / \mathrm{kg}$ $\mathrm{LW}^{0.75}$ /day, which at the highest level carried a $\sim 20 \%$ risk of causing animal production effects for $15 \%$ of the samples. AR1 and AR37 pastures, used as controls, contained nil or trace amounts of ergovaline.

Keywords: alkaloid, Epichloë festucae var. lolii, Lolium

\section{Introduction}

The perennial ryegrass endophyte Epichloë festucae var lolii provides the plant protection against insect attack by producing alkaloids, mainly lolitrem B, peramine, ergovaline and epoxy-janthitrems (Popay \& Hume 2011). These compounds, apart from peramine, can be associated with detrimental effects on animals at particular levels of intake. Lolitrem B is a neuro-toxin associated with the neuromuscular disorder 'ryegrass staggers' in grazing animals (di Menna et al. 2012). Some strains of Epichloë festucae var. lolii endophyte including AR1 (Fletcher 1999a), AR37 (Hunt \& Newman 2005) and NEA2 (Tian et al. 2013) produce little or no lolitrem B and are commercially marketed in perennial ryegrass as offering insect protection with reduced likelihood of animal health and production issues.

NEA2 and AR37 produce the alkaloids ergovaline and epoxy-janthitrems, respectively, that can have detrimental animal affects above certain intake levels. Epoxy-janthitrems are tremorgenic compounds (Finch et al. 2012) and AR37 is marketed with the caveat that it can cause ryegrass staggers (https://www.agricom. co.nz/rd/endophyte-information/ar37).

Ergovaline plays a role in producing physiological effects in animals similar to those of fescue toxicosis, with a review by Klotz \& Nicol (2016) concluding the

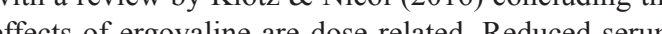
serum esed respiration rate have been reported at low ergovaline intake (0.02$0.04 \mathrm{mg} / \mathrm{kg} \mathrm{LW} 0.75 / \mathrm{day})$, increased core temperature at moderate intake $\left(0.04-0.06 \mathrm{mg} / \mathrm{kg} \mathrm{LW}{ }^{0.75} /\right.$ day $)$, and economically important symptoms of reduced DM intake, milk production or liveweight gain usually associated with ergovaline intake above $0.07 \mathrm{mg} / \mathrm{kg}$ $\mathrm{LW}^{0.75} /$ day. The review concluded that "quantitative data on the ergovaline profiles of novel endophytes in both the grazed and residual portions of the pasture are needed".

This study aimed to measure ergovaline concentration in the grazed component of several perennial ryegrass cultivars containing novel or SE, including the diploid commercially sold as 'Trojan NEA2' and the tetraploid cultivar sold as 'Bealey NEA2'. Ryegrass stubble, below a simulated grazing height $(4-5 \mathrm{~cm})$, could not be tested in this study as the National Forage Variety Variety Trial (NFVT) protocol stipulates that grass plots canno be cut to ground level.

When NEA2 was released it was believed to be single endophyte strain, but subsequent genotyping showed it is a mix of several endophytes. 'Trojan NEA2', as sold and used in this study, contains two biochemically distinct endophytes (NEA2 and NEA6, both protected by Plant Variety Rights) and each representing approximately $50 \%$ of the endophyte content (breeding lines a testedbefore ' markers, NEA6 in 'Trojan' has been shown to be two separate endophyte strains (Fletcher et al. 2017), however, alkaloid analysis has shown that their profiles are similar (unpublished data). 'Bealey NEA2', as sold, contains two endophytes, approximately $85 \%$ of strain NEA2 and 15\% NEA6.

Three locations within the two New Zealand mega- 
environments for pasture production (Chapman et al. 2017a), one in the upper (Waikato) and two in the lower (Manawatu and Canterbury) were chosen. Pasture samples were taken to measure ergovaline concentration over 5 months (November to April) when it is at its highest (Easton 1999). These data were then combined with pasture intake data for lactating dairy cows on experimental dairy farms in Canterbury and the Waikato to give estimates of ergovaline intake. The ergovaline intakes were then compared to those of Nicol \& Klotz (2016) to assess the risk of ergovaline induced effects on animal health and production.

\section{Methods}

Pasture samples were taken from four National Forage Variety Trial sites; two non-irrigated sites in the Waikato (two adjacent sites at DairyNZ, Scott Farm, Newstead; 37077'S $175^{\circ} 36^{\prime}$ E) sown in 2014, a nonirrigated Manawatu site (Massey University, Number 4 Dairy Farm; $40^{\circ} 24^{\prime} \mathrm{S} 175^{\circ} 36^{\prime} \mathrm{E}$ ), and an irrigated site in Canterbury (Rolleston Dairy Farm; 43 $57^{\circ} \mathrm{S}$ $\left.172^{\circ} 31^{\prime} \mathrm{E}\right)$, both sown in 2015 . At Scott Farm, diploi and tetraploid ryegrass cultivars were established in separate but adjacent sites. 'Base AR37' provided a non-ergovaline control for the tetraploid site. All sites had four replicates in a row by column design, and were managed to broadly simulate rotational grazing under high nutrient supply as described by the NZPBRA (http://www.nzpbra.org/forage-trials/). Sites were maintained as ryegrass monocultures with herbicides applied to control grass and broadleaf weeds. The cultivar $\mathrm{x}$ endophyte combinations sampled, and endophyte percentage of seed sown at the sites are presented in Table 1.

Samples were taken from three replicate plots for each cultivar $\mathrm{x}$ endophyte combination at each site in December 2015, January, February, March, and April 2016. Pre-graze plots (2500-3000 kg DM/ha) were cut to a height of $4-5 \mathrm{~cm}$ with a mower; six subsamples from the catcher were removed and after mixing, a

Table 1 Regions, ryegrass $x$ endophyte combinations sampled, and the endophyte percentage of the seed sown. Base AR37 was the non-ergovaline Newstead.

\begin{tabular}{lccc}
\hline Cultivar/endophyte & Waikato & Manawatu & Canterbury \\
\hline 'Trojan NEA2' & 88 & 88 & 88 \\
'Bealey NEA2'* & $90^{*}$ & 86 & 86 \\
'Bronsyn SE' & 98 & 98 & 98 \\
'Trojan AR1' & 99 & 98 & 98 \\
'Base AR37'* & not tested & & \\
\hline
\end{tabular}

*tetraploid site at Newstead, Waikato.
$200 \mathrm{~g}$ fresh weight (FW) of this herbage was placed in a plastic bag, sealed, and placed on dry ice. Samples were stored frozen $\left(<-18^{\circ} \mathrm{C}\right)$ before freeze-drying. Freeze-dried samples were chopped, mixed and ground $(<1 \mathrm{~mm}$ sieve) on a Cyclone Sample Mill (Thomas Scientific, 1654 High Hill Rd, Swedesboro, NJ 08085, USA) and stored in sealed vials at $2^{\circ} \mathrm{C}$ and $20 \%$ relative humidity.

Ergovaline analysis was undertaken by the AgriBio Science Centre, 5 Ring Rd, Bundoora VIC 3083, Australia (unpublished method). For cross-checking, a subset of 30 replicate samples was analysed for ergovaline concentration by AgResearch Ltd, Palmerston North, New Zealand (Moore et al. 2015).

Estimated cow dry matter intake of pasture and supplement was obtained from Waikato (Newstead) and Canterbury (Lincoln) DairyNZ P21 experimental farms (https://www.dairynz.co.nz/about-us/research part-21/) from pre- and post-grazing pastre moss ture mass assere calibrated plate meter (www.dairynz. co.nz). Both sites ran two farm systems, a 'low input high efficiency' system (LSE) and a 'high input high efficiency' system (HSE) in Canterbury, and a 'current' and 'future' system in Waikato as described in Chapman et al. (2017b). Pasture composition was assessed monthly by sampling herbage before dissecting a subsample into component species, drying and weighing. Cow liveweight and milksolids production were also recorded a d conved to monty mean velues. The average estinted ryegras dy mary ine for each me was con was combined with cow liveweight and the herbage ergovaline concentration $(\mathrm{mg} / \mathrm{kgDM})$ to calculate ergovaline intake of cows ( $\mathrm{mg} / \mathrm{kg} \mathrm{LW}^{0.75} /$ day). Ergovaline concentrations were statistically analysed with a linear mixed model (fitted by REML) using Genstat 18 (VSN International 2015) which accounts for the unbalanced occurrence of cultivars in sites and the pooled samples (for the Canterbury December hampling the 3 initiat pots for each tretnent were accidentally pooled before being analysed). The data were log-transformed, and separate variances for each site were fitted along with strata for replicates, plots and harvest dates within plots. The fixed model was (site $\mathrm{x}$ cultivar $\mathrm{x}$ time) (all site by cultivar by time combinations) and the random model was site/ replicates/plot/time (time periods nested in plots, nested in replicates, nested in reticates, nith no detectable enovalne has of the ninimum detectable level substitued for their value to enable the data to be logged. Where all observations of a cultivar or site had no detectable alkaloid, that entry was removed from the analysis so that the standard errors were not biased downwards. Ergovaline concentration data from different laboratories were assessed by regression analysis.
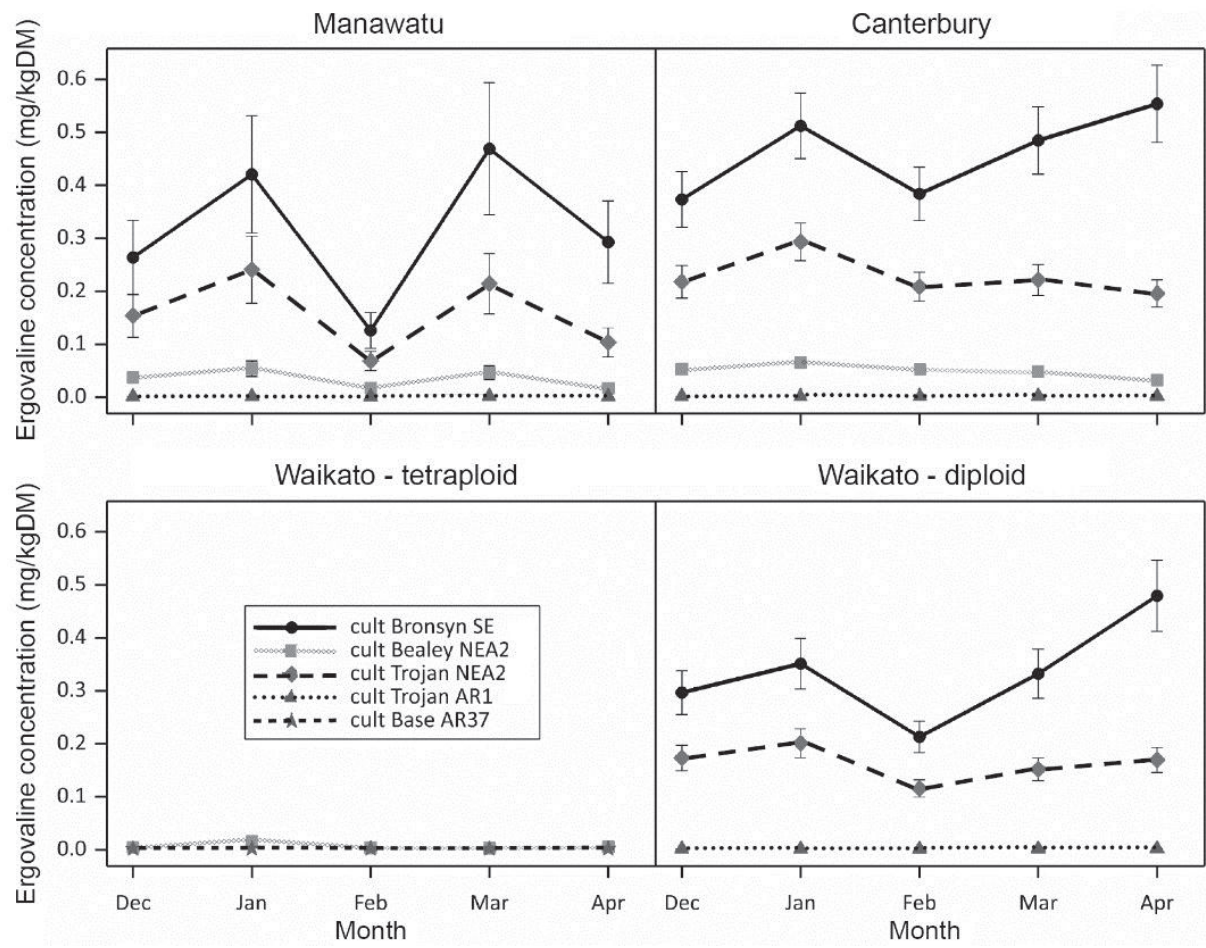

Figure 1 Mean ergovaline concentration $(\mathrm{mg} / \mathrm{kg} \mathrm{DM})$ of the cultivar $x$ endophyte combinations in the grazed zone (above $4-5 \mathrm{~cm}$ ) from December 2015 to April 2016 at the four sites. LSD given as bars.

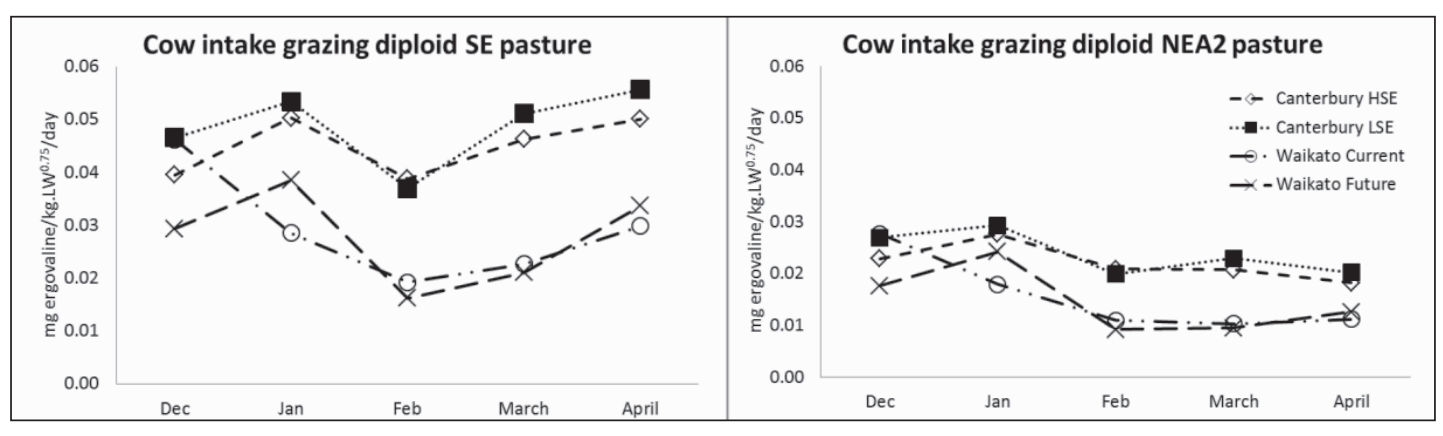

Figure 2 Estimated ergovaline intake of dairy cows ( $\mathrm{mg} / \mathrm{kg}$ LWo.75/day) for the diploid SE ryegrass (left) versus diploid NEA2 ryegrass (right), based on data from four dairy farm systems.

\section{Results}

Regression analysis of the ergovaline concentrations from the 30 paired samples analysed by AgriBio Science Centre and AgResearch showed a high level of agreement with the constant not significantly different from 0 , the slope not significantly different from 1 , and an overall $95.5 \%$ correlation (data not shown).

Over all sites and months the mean ergovaline concentration in diploid 'Bronsyn SE' was $0.21 \mathrm{mg} / \mathrm{kg}$ DM, higher than diploid 'Trojan NEA2' $(0.11 \mathrm{mg} / \mathrm{kg}$ $\mathrm{DM})$, which in turn was higher than in the tetraploid 'Bealey NEA2' $(0.02 \mathrm{mg} / \mathrm{kg}$ DM) $(\mathrm{P}<0.05$ in all cases $)$. Ergovaline concentration varied over time, and was lower in February than in January or March $(\mathrm{P}<0.05)$. There were a small but significant $(\mathrm{P}<0.01)$ cultivar $\mathrm{x}$ site and cultivar $\mathrm{x}$ time interaction but these were only $5 \%$ of the variation due to the main effects, and id not change the rankings between the cultivars, although there were small changes in the relative differences (Figure 1).

The estimated ergovaline intake of cows $(\mathrm{mg} / \mathrm{kg}$ $\mathrm{LW}^{0.75} /$ day) for the four associated farm systems were calculated (Appendix), with intake of diploid SE and diploid NEA2 cultivars presented in Figure 2. For SE the estimated ergovaline intake for cows ranged from $0.016-0.046 \mathrm{mg} / \mathrm{kg} \mathrm{LW}$.0.75/day for the Waikato, 
and $0.037-0.056$ for Canterbury. The diploid NEA2 ergovaline intake ranged from $0.009-0.029 \mathrm{mg} / \mathrm{kg}$ $\mathrm{LW}^{0.75} /$ day. For tetraploid NEA2 and control cultivar the intakes were negligible (below $5 \times 10^{-3}$ ).

\section{Discussion}

Ergovaline concentration in herbage

The ergovaline concentrations in the pasture above the $4-5 \mathrm{~cm}$ cutting height, representing the grazed zone of ryegrass (Figure 1) are consistent with those of Lane et al. (1997), who reported $\sim 0.25 \mathrm{mg} / \mathrm{kg}$ DM for leaf, and Spiering et al. $(2002,2005)$ who reported $0-0.15 \mathrm{mg}$ / $\mathrm{kg}$ DM in leaves.

Ergovaline concentration did not follow the expected seasonal pattern of rising through summer before falling in late autumn (Fletcher et al. 2000; Thom et al. 2013) for any of the sites, although levels at the Manawatu site did drop in April (Figure 1). Ergovaline concentration in Canterbury and Waikato pastures did not drop ir to February being the second warmest on record in New Zealand (NIWA 2017). All sites recorded a dip in ergovaline concentration in February. It was assumed that the warmer North Island sites would have higher ergovaline concentrations (Fletcher et al. 1999b), however, the Canterbury site showed the highest values.

Most commonly, ergovaline concentration has been reported from harvesting pasture to ground level, a this provides a consistent cutting height for sampling. However, as ergovaline concentration increases toward the base of SE containing ryegrass plants (Spiering et al. 2005), with up to a 10 -fold greater concentration in the plant crown (Lane et al. 1997), harvesting to ground level is likely to result in an overestimate of ergovalin intake $\left(\mathrm{mg} / \mathrm{kg} \mathrm{LW}{ }^{0.75} / \mathrm{day}\right)$ by stock. In this work, pastures were sampled to an estimated 'grazed horizon', using recommended pre- and post-graze levels (e. DairyNZ 2017a; DairyNZ 2017b), to provide (more appropriate levels of ergovaline concentration $(\mathrm{mg} / \mathrm{kg}$ $\mathrm{DM})$ in the herbage ingested by grazing animals.

The high level of agreement in the analysis of paired samples between two laboratories adds confidence in the ergovaline concentration data reported by other authors in New Zealand.

\section{Ergovaline intake by cows}

This study provides a framework for estimating ergovaline intake by grazing animals, and the likelihood of any adverse effects on them.

The estimated ergovaline intakes of cows in all the NEA2-based systems (Figure 2) were less than 0.03 $\mathrm{mg} / \mathrm{kg} \mathrm{LW}$. $75 /$ day, a level below which no significan effects on animal production or liveweight gain have been reported (Nicol \& Klotz 2016). This study suggests that the ergovaline intake of dairy cows from well managed NEA2-based ryegrass pasture is unlikely to affect animal health or production.

For SE pastures the intake range was $0.037-0.056$ $\mathrm{mg} / \mathrm{kg} \mathrm{LW}$.075/day in Canterbury, higher than the $0.016-0.046 \mathrm{mg} / \mathrm{kg} \mathrm{LW}$.075/day in Waikato. The highest ergovaline intakes correspond to a $20 \%$ chance of animal production effects in Canterbury in January, March and April, and a 15\% chance of ergovaline effects in the Waikato in January according to the criteria used by Nicol \& Klotz (2016)

In practice, the ergovaline intake from ryegrass by dairy cows is often diluted by the mixed botanical composition of pasture, feeding of summer crops such as chicory or turnips, and the supply of supplements such as grain or silage. A major difference in the DairyNZ P21 farms was their pasture botanical composition, with an average ryegrass content of $79.8 \%$ in Canterbury and only $54.8 \%$ in the Waikato, throughout the sampling period. The lower levels in the Wrases kown (Field \& Forde 1990) and not hosts of Epichloë-type endophytes (Clay 1990).

While it is has been suggested that ergovaline effects might be more likely in northern New Zealand due to climate induced elevated ergovaline concentrations (Fletcher et al. 1999b), this study indicates that this is not necessarily the case. Overall ryegrass ergovaline concentrations were lower in the Waikato than Canterbury, and the lower ryegrass content in Waikato pastures and more common feeding of summer crops and supplements may naturally mitigate ergovaline intake, by reducing the level of ryegrass intake.

Whether ergovaline intake ( $\mathrm{mg} / \mathrm{kg} \mathrm{LW}^{0.75} /$ day) would change if animals grazed below the $4-5 \mathrm{~cm}$ sampling height used in this study cannot be determined. While ergovaline concentration are higher in the bose of a pasture than the grazed region (Spiering et al. 2005 , Lane et al. 1997), this is usually counter-balanced by a reduced DM intake as animals graze closer to the ground as a result of decreased bite size and intake rate (Cosgrove \& Edwards 2007).

The ergovaline intake from NEA2 pastures was below the $0.475 \mathrm{mg} / \mathrm{kg}$ DM (or $0.045 \mathrm{mg} / \mathrm{kg} \mathrm{LW}^{0.75}$ / day) threshold level for fescue induced ergovaline effects suggested by Stamm et al. (19 \& Merill (2006), respecively. Also, La \& Merill (2006), suggested that fescue and ryegrass ergot profiles are
different with symptoms caused by ergovaline in fescue seemingly much stronger.

In the Nicol \& Klotz (2016) review only four papers reported negative effects of ergovaline intake on production (liveweight gain or milk yield) when intake was below $0.07 \mathrm{mg} / \mathrm{kg} \mathrm{LW}{ }^{0.75} /$ day, all of which involved SE, and thus could not be separated from the possible effect of the associated lolitrem B. The lolitrem $B$ concentration of NEA2 containing ryegrass in this simulated grazed zone was below the threshold for detection ( 0.05 ppm), so NEA2, will likely avoid any possible additive effects of these alkaloids as suggested by Bluett et al. (2001).

\section{Conclusion}

To date there is no perfect endophyte commercially available, and farmers and plant breeders must balance the advantages of insect control and plant persistence of different endophyte strains, with potential disadvantages of animal welfare and production issues.

This study provided a framework for estimating ergovaline intake by stock, and suggests that the ergovaline intake of dairy cows from well managed NEA2-based ryegrass pastures is unlikely to affect animal health or production.

\section{ACKNOWLEDGEMENTS}

Chris Roach and Anna Clement of DairyNZ for providing the P21 farm systems data. David Baird for statistical analysis. DairyNZ for assistance in funding this work

\section{REFERENCES}

Bluett, S.J.; Hodgson, J.; Kemp, P.D.; Barry, T.N. 2001. Performance of lambs and the incidence of staggers and heat stress on two perennial ryegrass (Lolium perenne) cultivars using a leader-follower rotational grazing management system. Journal of Agricultural Science, Cambridge 136: 99-110.

Bluett, S.J.; Thom, E.R.; Clark, D.A.; Macdonald, K.A.; Minneé, E.M.K. 2005. Effects of perennial ryegrass infected with either AR1 or wild type endophyte on dairy production in the Waikato New Zealand Journal of Agricultural Research 48: 197-212

Bohnert, D.W.; Merrill, M.L. 2006. Management strategies for use of high-alkaloid grass seed straw. pp. 113-125. In: Proceedings of the 41st Annual Pacific Northwest Nutrient Conference, Vancouver, British Columbia, Canada. Ed. von Keyserlingk, M. CR Press Inc., Portland, OR

Brock, J.L.; Thomas, V.J. 1991. The pasture ryegrass plant, what is it? Proceedings of the New Zealand Grassland Association 53:111-116.

Chapman, D.F.; Bryant, J.R.; Olayemi, M.E.; Edwards, G.R. Thorrold, B.S.; McMillan, W.H.; Kerr, G.A.; Judson, G.; Cookson, T.; Moorhead, A.; Norriss, M. 2017a. An economically based evaluation index for perennial and short-term ryegrasses in New Zealand dairy farm systems. Grass and Forage Science 72: 1-21. Chapman, D.F.; Macdonald, K.A.; Dalley, D.; Shepherd, M.A.; Monaghan, R.M.; Edwards, G.R. 2017b. Principles from Pastoral 21: Optimising dairy system strategies to meet nutrient limits. DairyNZ Technical Series in brief 33 (March 2017): 9-13.

Clay, K. 1990. Fungal endophytes of grasses. Annual Review of Ecology and Systematics 21: 275-297.

Cosgrove, G.P.; Edwards, G.R. 2007. Control of grazing intake. pp. 61-80. In: Pasture and supplements for grazing animals. No. 14. Eds. Rattray, P.V.; Brookes, I.M.; Nicol, A.M. New Zealand Society of Animal Production.

DairyNZ. 2017a. Pasture Allocation. Accessed: 09/05/17. https://www.dairynz.co.nz/feed/pasturemanagement/assessing-and-allocating-pasture/ pasture-allocation/

DairyNZ. 2017b. Perennial ryegrass grazing management in spring - Paddock guide.

di Menna, M.E.; Finch, S.C.; Popay, A.J.; Smith, B.L. 2012. A review of the Neotyphodium lolii/Lolium perenne symbiosis and its associated effects on animal and plant health, with particular emphasis on ryegrass staggers. New Zealand Veterinary Journal 60: $315-328$

Easton, H.S. 1999. Endophyte in New Zealand ryegrass pastures, an overview. Grassland Research and Practice Series 7: 1-9.

Emile, J.C.; Bony, S.; Ghesquiere, M. 2000. Influence of consumption of endophyte-infested tall fescue hay on performance of heifers and lambs. Journal of Animal Science 78: 358-364

Field, T.R.O.; Forde, M.B. 1990. Effects of climate warming on the distribution of $\mathrm{C} 4$ grasses in New Zealand. Proceedings of the New Zealand Grassland Association 51: 47-50.

Finch, S.C., Fletcher, L.R., Babu, J.V. 2012. The valuation of endophyte toxin residues in sheep fat. New Zealand Veterinary Journal 60: 56-60.

Fletcher, L.R. 1999a. 'Non-toxic' endophytes in ryegrass and their effect on livestock health and production. Grassland Research and Practice Series 7: 133-139.

Fletcher, L.R.; Sutherland, B.L.; Fletcher, C.G. 1999b. The impact of endophyte on the health and productivity of sheep grazing ryegrass-based pastures. Grassland Research and Practice Series 7: 11-17.

Fletcher, L.R.; Lane, G.A.; Baird, D.B.; Davies, E. 2000. Seasonal variation of alkaloid concentrations in two perennial ryegrass-endophyte associations. pp. 535-541. In: Fourth International Neotyphodium/ grass interactions symposium. Eds. Paul, H.V Dapprich, P.D. Soest, Germany.

Fletcher, L.R.; Finch, S.C.; Sutherland, B.L.; deNicolo, G.; Mace, W.J.; van Koten, C.; Hume, D.E. 2017. The occurrence of ryegrass staggers and heat stress in sheep grazing ryegrass endophyte associations with diverse alkaloid profiles. New Zealand Veterinary Journal. DOI: 10.1080/00480169.2017.1329673 
Hunt, M.G.; Newman, J.A. 2005. Reduced herbivore resistance from a novel grass-endophyte association. Journal of Applied Ecology 42: 762-769 Klotz, J.L.; Nicol, A.M. 2016. Ergovaline, an endophytic alkaloid. 1. Animal physiology and metabolism. Animal Production Science 56: 1761-1774

Lane, G.A.; Ball, O.J.-P.; Davies, E.; Davidson, C. 1997. Ergovaline distribution in perennial ryegrass naturally infected with endophyte. pp. 65-67. In Neotyphodium/Grass Interactions. Eds. Bacon, C.W.; Hill, N.S. Plenum Press, New York \& London. Liarzi, O.; Ezra, D. 2013. Endophyte mediated biocontrol of herbaceous and non-herbaceous plants. pp. 335-369. In: Advances in Endophytic Research. Eds. Verma, V.C.; Gange A.C. Springer.

Joseph, R.; Moore, J.R.; James, E.; Pratley, J.E.; Wade J.; Mace, W.J.; Leslie, A.; Weston, L.A. 2015. Variation in alkaloid production from genetically diverse Lolium accessions infected with Epichloë species. Journal of Agriculture and Food Chemistry 63: $10355-10365$.

Nicol, A.M.; Klotz, J.L. 2016. Ergovaline, an endophytic alkaloid. 2. Intake and impact on anima production, with reference to New Zealand. Animal Production Science 56:1775-1786

NIWA. 2017. Monthly climate summaries from December 2001 to the present. https://www.niwa co.nz/climate/summaries/monthly

Popay, A.J.; Hume D.E.; Davis K.L.; Tapper B.A. 2003. Interactions between endophyte (Neotyphodium spp.) and ploidy in hybrid and perennial ryegrass cultivars and their effects on Argentine stem weevi (Listronotus bonariensis). New Zealand Journal of Agricultural Research 46: 311-319.

Popay, A.J.; Hume, D.E. 2011. Endophytes improve ryegrass persistence by controlling insects. Grassland Research and Practice Series 15: 149-156.

Richardson, M.D.; Cabrera, R.I.; Murphy, J.A.; Zaurov, D.E. 1999. Nitrogen form and endophyte infection effects on growth, nitrogen uptake, and alkaloid content of chewings fescue turf grass. Journal of Plant Nutrition 22: 67-79.

Spiering, M.J.; Davies, E.; Tapper, B.A.; Schmid, J.; Lane, G.A. 2002. Simplified extraction of ergovaline and peramine for analysis of tissue distribution in endophyte-infected grass tillers. Journal of Agriculture and. Food Chemistry 50: 5856-5862.

Spiering, M.J., Lane, G.A., Christensen, M.J., Schmid, J. 2005. Distribution of the fungal endophyte Neotyphodium lolii is not a major determinant of the distribution of fungal alkaloids in Lolium perenne plants. Phytochemistry 66: 195-202.

Stamm, M.M.; DelCurto, T.; Horney, M.R.; Brandyberry, S.D.; Barton, R.K. 1994. Influence of alkaloid concentration of tall fescue straw on the nutrition, physiology, and subsequent performance of beef steers. Journal of Animal Science 72: 10681075.

hom, E.R.; Waugh, C.D.; Minneé, E.M.; Waghorn, G.C. 2013. Effects of novel and wild-type endophytes in perennial ryegrass on cow health and production. New Zealand Veterinary Journal 61: 87-97.

Tian, P.; Le, T-N.; Ludlow, E. J.; Smith, K. F.; Forster, J.W.; Guthridge, K.M.; Spangenberg, G.C. 2013. Characterisation of novel perennial ryegrass hostNeotyphodium endophyte associations. Crop and Pasture Science 64: 716-725.

VSN International. 2015. Genstat for Windows 18th Edition. VSN International, Hemel Hempstead, UK.
Appendix Calculation of estimated ergovaline intake of dairy cows on four farmlets

Canterbury (top) and Waikato (bottom) experimental farm systems. Data for: cow weight, milksolids production, pasture diploid SE and diploid NEA2 ryegrass $x$ endophyte combinations.

\begin{tabular}{|c|c|c|c|c|c|c|}
\hline Canterbury & High SE & & & & & \\
\hline Month & Dec & Jan & Feb & Mar. & April & Av. \\
\hline Av. Cow weight (kg) & 502 & 506 & 511 & 519 & 524 & 512 \\
\hline Mean daily milksolids (kg) & 2.0 & 1.8 & 1.7 & 1.7 & 1.5 & 1.7 \\
\hline Total intake (kg DM/day) & 17.0 & 16.0 & 18.3 & 18.9 & 17.0 & 17.4 \\
\hline Silage (kg DM/day) & 1.1 & 0.5 & 2.2 & 3.4 & 2.4 & 1.9 \\
\hline Grain (kg DM/day) & 2.7 & 2.6 & 3.4 & 3.7 & 3.5 & 3.2 \\
\hline Pasture intake (kg DM/day) & 13.2 & 13.0 & 12.8 & 11.8 & 11.2 & 12.4 \\
\hline Clover (\%) & 12.5 & 15.0 & 12.5 & 9.0 & 7.0 & 11.2 \\
\hline Other (\%) & 4.0 & 4.0 & 4.0 & 4.0 & 4.0 & 4.0 \\
\hline Ryegrass (\%) & 83.5 & 81.0 & 83.5 & 87.0 & 89.0 & 84.8 \\
\hline NEA2 ergovaline (mg/kg DM) & 0.2 & 0.3 & 0.2 & 0.2 & 0.2 & 0.2 \\
\hline NEA2 ergovaline (mg/cow/day) & 2.4 & 2.9 & 2.2 & 2.3 & 2.0 & 2.4 \\
\hline SE ergovaline (mg/kg DM) & 0.4 & 0.5 & 0.4 & 0.5 & 0.6 & 0.5 \\
\hline SE ergovaline (mg/cow/day) & 4.2 & 5.4 & 4.2 & 5.0 & 5.5 & 4.8 \\
\hline Cow LW $\mathrm{LW}^{0.75}$ & 106.1 & 106.7 & 107.5 & 108.7 | & 109.5 & 107.7 \\
\hline $\begin{array}{l}\text { NEA2 Ergovaline intake } \\
\left(\mathrm{mg} / \text { cow/kg LW } \text { LW }^{0.75} / \mathrm{day}\right)\end{array}$ & 0.023 & 0.028 & 0.021 & 0.021 & 0.018 & 0.022 \\
\hline $\begin{array}{l}\text { SE Ergovaline intake } \\
\text { (mg/cow/kgLW }{ }^{0.75} / \text { day) }\end{array}$ & 0.039 & 0.050 & 0.039 & 0.046 & 0.050 & 0.045 \\
\hline Waikato & Current & & & & & \\
\hline Av. Cow weight (kg) & 475 & 481 & 483 & 496 & 508 & 489 \\
\hline Mean daily milksolids (kg) & 1.6 & 1.3 & 1.1 & 0.9 & 0.7 & 1.1 \\
\hline Total intake (kg DM/day) & 16.9 & 15.9 & 22.0 & 20.1 & 15.8 & 18.1 \\
\hline Silage (kg DM/day) & 0.0 & 0.0 & 2.0 & 2.9 & 3.1 & 1.6 \\
\hline Grain (kg DM/day) & 0.0 & 0.0 & 0.0 & 0.0 & 0.0 & 0.0 \\
\hline Pasture intake (kg DM/day) & 16.9 & 15.9 & 20.0 & 17.2 & 12.7 & 16.5 \\
\hline Clover (\%) & 5.1 & 13.5 & 9.1 & 3.7 & 7.5 & 7.8 \\
\hline Other (\%) & 2.2 & 33.9 & 43.7 & 54.3 & 40.1 & 34.8 \\
\hline Ryegrass (\%) & 92.7 & 52.6 & 47.2 & 42.0 & 52.4 & 57.4 \\
\hline \begin{tabular}{|l|} 
NEA2 ergovaline (mg/kg DM) \\
\end{tabular} & 0.2 & 0.2 & 0.1 & 0.2 & 0.2 & 0.2 \\
\hline NEA2 ergovaline (mg/cow/day) & 2.8 & 1.8 & 1.1 & 1.1 & 1.2 & 1.6 \\
\hline SE ergovaline (mg/kg DM) & 0.3 & 0.4 & 0.2 & 0.3 & 0.5 & 0.3 \\
\hline SE ergovaline (mg/cow/day) & 4.7 & 2.9 & 2.0 & 2.4 & 3.2 & 3.0 \\
\hline Cow LW & 101.7 & 102.7 & 103.0 & \begin{tabular}{|l|l|}
105.1 \\
\end{tabular} & 107.0 & 103.9 \\
\hline $\begin{array}{l}\text { NEA2 Ergovaline intake } \\
\text { (mg/cow/kg LW } \\
0.75 / \text { day) }\end{array}$ & 0.028 & 0.018 & 0.011 & 0.010 & 0.011 & 0.016 \\
\hline $\begin{array}{l}\text { SE Ergovaline intake } \\
\left(\mathrm{mg} / \text { cow/kgLW }^{0.75} / \text { day) }\right.\end{array}$ & 0.046 & 0.028 & 0.019 & $\mid 0.023$ & $\mathbf{0 . 0 3 0}$ & 0.029 \\
\hline
\end{tabular}

\begin{tabular}{|c|c|c|c|c|c|}
\hline Low SE & & & & \\
\hline Dec & Jan & Feb & Mar. & April & Av. \\
\hline 509 & 519 & 518 & 529 & 542 & $\mathbf{5 2 3}$ \\
\hline 2.0 & 1.9 & 1.8 & 1.7 & 1.5 & $\mathbf{1 . 8}$ \\
\hline 16.7 & 15.7 & 17.1 & 17.5 & 16.4 & $\mathbf{1 6 . 7}$ \\
\hline 0.0 & 0.0 & 1.3 & 1.0 & 2.3 & $\mathbf{0 . 9}$ \\
\hline 0.5 & 0.1 & 0.2 & 0.3 & 0.5 & $\mathbf{0 . 3}$ \\
\hline 16.2 & 15.6 & 15.6 & 16.2 & 13.7 & $\mathbf{1 5 . 5}$ \\
\hline 15.0 & 23.0 & 30.0 & 25.0 & 13.0 & $\mathbf{2 1 . 2}$ \\
\hline 4.0 & 4.0 & 4.0 & 4.0 & 4.0 & $\mathbf{4 . 0}$ \\
\hline 81.0 & 73.0 & 66.0 & 71.0 & 83.0 & $\mathbf{7 4 . 8}$ \\
\hline 0.2 & 0.3 & 0.2 & 0.2 & 0.2 & $\mathbf{0 . 2}$ \\
\hline 2.9 & 3.2 & 2.2 & 2.5 & 2.3 & $\mathbf{2 . 6}$ \\
\hline 0.4 & 0.5 & 0.4 & 0.5 & 0.6 & $\mathbf{0 . 5}$ \\
\hline 5.0 & 5.8 & 4.0 & 5.6 & 6.3 & $\mathbf{5 . 3}$ \\
\hline 107.2 & 108.7 & 108.6 & 110.3 & 112.3 & $\mathbf{1 0 9 . 4}$ \\
\hline $\mathbf{0 . 0 2 7}$ & $\mathbf{0 . 0 2 9}$ & $\mathbf{0 . 0 2 0}$ & $\mathbf{0 . 0 2 3}$ & $\mathbf{0 . 0 2 0}$ & $\mathbf{0 . 0 2 4}$ \\
\hline & & & & & \\
\hline $\mathbf{0 . 0 4 7}$ & $\mathbf{0 . 0 5 3}$ & $\mathbf{0 . 0 3 7}$ & $\mathbf{0 . 0 5 1}$ & $\mathbf{0 . 0 5 6}$ & $\mathbf{0 . 0 4 9}$ \\
\hline Future & & & & & \\
\hline 501 & 492 & 480 & 483 & 486 & $\mathbf{4 8 8}$ \\
\hline 1.8 & 1.5 & 1.1 & 0.9 & 0.8 & $\mathbf{1 . 2}$ \\
\hline 16.5 & 17.8 & 22.7 & 18.9 & 15.6 & $\mathbf{1 8 . 3}$ \\
\hline 0.0 & 0.0 & 1.9 & 2.9 & 2.4 & $\mathbf{1 . 4}$ \\
\hline 0.0 & 0.0 & 0.0 & 0.0 & 0.0 & $\mathbf{0 . 0}$ \\
\hline 16.5 & 17.8 & 20.8 & 16.0 & 13.2 & $\mathbf{1 6 . 9}$ \\
\hline 23.9 & 13.5 & 4.3 & 4.7 & 9.9 & $\mathbf{1 1 . 3}$ \\
\hline 13.3 & 21.9 & 57.7 & 54.3 & 35.1 & $\mathbf{3 6 . 5}$ \\
\hline 62.8 & 64.6 & 38.0 & 41.0 & 55.0 & $\mathbf{5 2 . 3}$ \\
\hline 0.2 & 0.2 & 0.1 & 0.2 & 0.2 & $\mathbf{0 . 2}$ \\
\hline 1.9 & 2.5 & 0.9 & 1.0 & 1.3 & $\mathbf{1 . 5}$ \\
\hline 0.3 & 0.4 & 0.2 & 0.3 & 0.5 & $\mathbf{0 . 3}$ \\
\hline 3.1 & 4.0 & 1.7 & 2.2 & 3.5 & $\mathbf{2 . 9}$ \\
\hline 105.9 & 104.5 & 102.5 & 103.0 & 103.5 & $\mathbf{1 0 3 . 9}$ \\
\hline $\mathbf{0 . 0 1 8}$ & $\mathbf{0 . 0 2 4}$ & $\mathbf{0 . 0 0 9}$ & $\mathbf{0 . 0 1 0}$ & $\mathbf{0 . 0 1 3}$ & $\mathbf{0 . 0 1 5}$ \\
\hline & & & & & \\
\hline $\mathbf{0 . 0 2 9}$ & $\mathbf{0 . 0 3 9}$ & $\mathbf{0 . 0 1 6}$ & $\mathbf{0 . 0 2 1}$ & $\mathbf{0 . 0 3 4}$ & $\mathbf{0 . 0 2 8}$ \\
\hline & & & & & \\
\hline
\end{tabular}

